\title{
SANKSI PIDANA DIYAT SEBAGAI ALTERNARTIF MEMINIMALISIR PERMASALAHAN OVERCROWDING PENJARA DI INDONESIA
}

\author{
DIYAT CRIMINAL SANCTION AS ALTERNATIVE IN ORDER \\ TO MINIMIZE PRISONS OVERCROWDING PROBLEM IN \\ INDONESIA
}

\author{
Kuswandi \\ Universitas Suryakancana \\ Email : kuswandi_fh@yahoo.co.id \\ Henny Nuraeny \\ Universitas Suryakancana \\ Email : hennynuraeny28@gmail.com \\ Cucu Solihah \\ Universitas Suryakancana \\ Email : cucusolihah2012@gmail.com
}

\begin{abstract}
Abstrak
Kondisi Overcrowding penjara merupakan konsekwensi dari tingginya suplay para narapidana dan tahanan sebagai mata rantai system pemidanaan di Indonesia, over kapasitas jumlah penghuni lapas mencapai 107 \% denganpertumbuhahnkenaikan narapidana 22.000 per tahun beresiko terhadap fasilitas yang tidak memadai, tingginya biaya operasional lapas juga sangat memungkinkan adanya potensi pelanggaran terhadap hak-hak dasar para narapidana dan tahanan sebagai manusia. Tujuan dari artikel ini yaitu untuk menganalisis alternartif sanksi pidana dengan gan tirugi (diyat) untuk meminimalisir permasalahan overcrowding penjara di Indonesia. Kesimpulan dari artikel ini yaitu perlu dikembangkan sebuah konsep pemidahaan yang sesuai dengan tujuan pemidanaan sebagai "law abiding citizens" melalui perubahan paradigma "menghukum dan pembalasan" dengan mengembalikan harga diri para narapidana dengan memperlakukan dan menganggap para narapidana sebagai manusia yang berpotens iuntuk menjadi manusia baik, selain itu juga perlu dikembangkan sanksi pidana gantirugi (diyat) pada kasus-kasus tertentu sebagai pengganti dari sanksi pidana kurungan yang selama ini ada di dalam KUHP dan peraturan perundang-undangan lainnya.
\end{abstract}

\section{Keyword: Diyat, Narapidana. Overcrowding.}

\begin{abstract}
Prison overcrowding is a consequence of the high supply of prisoners as a chain of criminal justice systems in Indonesia, over capacity of prison inmates reaching $107 \%$ with a growth in prisoner increase of 22,000 per year at risk of inadequate facilities, high operational costs of prisons also very likely the potential for violations to the basic rights of prisoners as humans. The purpose of this article is to analyze the alternative criminal sanctions with compensation (diyat) to minimize the problem of prison overcrowding in Indonesia. The conclusion of this article is that it is necessary to develop a criminal concept that is in line with the goal of punishment as a "law abiding citizens" through a paradigm shift "to punish and retaliate" by restoring the dignity of prisoners by treating
\end{abstract}


prisoners as human beings who have the potential to become good human beings, besides that criminal sanctions also need to be developed compensation (diyat) in certain cases in lieu of imprisonment sanctions that have been in the Criminal Code and other laws and regulations.

Keyword:, Diyat, Overcrowding, Prisoners,

\section{PENDAHULUAN}

Pemberlakuan pidana penjara di Indonesi merupakan hukum peninggalan Kolonial Belanda yang bersifat punitif dan represif. Sifat ini tidak lain karena dipengaruhi oleh ajaran pemidanaan yang berlaku pada saat itu, yaitu retributif. Menurut teori retributif, hukuman diberikan karena pelaku kejahatan harus menerima hukuman itu demi kesalahan. Hukuman menjadi retribusi yang adil bagi kerugian yang diakibatkan oleh perbuatannya. Dengan demikian, menurut teori ini hukuman layak diberikan kepada pelaku kejahatan atas pertimbangan bahwa pelaku kejahatan terbukti melakukan suatu kejahatan. ${ }^{1}$

Evaluasi terhadap keberhasilan tujuan pemidanaan menjadi persoalan yang cukup dilematis, terutama dalam pemidanaan melalui kurungan di lembaga pemasyarakatan apakah pemidanaan ditujukan untuk melakukan pembalasan atas tindak pidana yang terjadi, atau merupakan tujuan yang layak dari proses pidana, yakni pencegahan tingkah laku yang anti sosial. ${ }^{2}$

Terdapat tiga faktor yang menyebabkan terjadinya gangguan keamanan dan ketertiban di dalam Lapas.Pertama, masih buruknya kondisi Lapas sebagai akibat dari persoalan kelebihan kapasitas. Kedua, masih lemahnya kemampuan Lapas untuk memenuhi hak-hak dasar Narapidana.memiliki posisi tawar, yaitu hubungan informal antara Narapidana dengan petugas. Melalui hubungan yang terjadi, kedua belah pihak saling memanfaatkan kondisi yang dapat mendatangkan keuntungan. Ketiga, terciptanya budaya penjara yang memungkinkan. ${ }^{3}$

Sanksi pidana berupa pidana penjara atau kurungan yang terdapat dalam KUHP dan di beberapa ketentuan peraturan perundang-undangan akan semakin memperparah kondisi lapas di Indonesia, terlebih jika difahami bahwa pemidanaan dimaksudkan sebagai alternatif terakhir (Ultimum remedium), maka mengsinergikan antara sanksi pidana penjara / kurungan dengan tujuan pemidanaan dan alternatif hukum pidana ganti rugi (diyat) menjadi hal yang sangat penting dan akan menjadi suatu kajian dan memberikan kontribusi keilmuan khususnya hukum pidana Islam dengan konsep ganti ruginya (diat), guna menyelesaikan persoalan kelebihan kapasitas di suatu lembaga pemasyarakatan dewasa ini.

Berdasarkan latar belakang pemikiran sebagaimana tersebut di atas, dapat dirumuskan permasalahan sebagai berikut :

1. Apa yang melatarbelakangi permasalahan overcrowding penjara di Indonesia?

2. Bagaimanaimplementasisanksipidanadiyat(gantirugi)sebagaialternatifpermasalahan overcrowding penjara di Indonesia? 19

${ }^{1}$ Dede Kania, 2014, Pidana Penjara Dalam Pembaharuan Hukum Pidana Indonesia,Yustisia, Vol. 3 No.2, hlm.

${ }^{2}$ Nafi’ Mubarok, Tujuan Pemidanaan dalam Hukum Pidana Nasional dan Fiqh Jinayah, Al-Qānūn,,Vol. 18, No. 2, Desember, 2015, ,hlm.300

${ }^{3}$ Iqrak Sulhim dalam Donny Michael,Penerapan Hak-Hak Narapidana Di Lembaga Pemasyarakatan Klas Ia Tanjung Gusta, Sumatera Utara Ditinjau Dari Perspektif Hak Asasi Manusia,, Jurnal Hak Asasi Manusia, Volume 6 No. 2, 2015, hlm. 92

40 Jurnal IUS Kajian Hukum dan Keadilan 
Penelitian ini menggunakan perspektif sociolegal. 'Legal' dalam sosio-legal, sesungguhnya terkait dengan studi ilmu hukum yang selama ini banyak dikembangkan dalam pendidikan hukum, terutama mengkaji norma, asas, prinsip, doktrin, interpretasi, dan nalar hukum (legal reasoning).Tujuan dari pendekatan ini adalah "pada akhirnya menggabungkan pengetahuan, keterampilan, dan bentuk pengalaman penelitiandari dua (atau beberapa) disiplin ilmu dalam upaya untuk mengatasi beberapa batasan teoritis dan metodologis disiplin ilmu yang bersangkutan dan menciptakan dasar untuk mengembangkan bentuk analisis yang baru". ${ }^{4}$

\section{PEMBAHASAN.}

\section{Teori dan Tujuan Pemidanaan.}

Pada dasarnya kejahatan merupakan suatu pola tingkah laku yang merugikan masyarakat sehingga menimbulkan korban, yang pada akhirnya melahirkan reaksi sosial. Salah satu bentuk reaksi sosial adalah adanya penal policy, yaitu strategi untuk menanggulangi kejahatan dengan menggunakan sarana hukum pidana. Dalam penal policy inilah perlu dirumusaan latar belakang atau alasan penggunaan pidana tersebut, atau yang biasa disebut dengan perumusan tujuan pemidanaan, yang mempunyai fungsi untuk (1) menciptakan sinkronisasi baik fisik maupun kultural; (2) fungsi kontrol, memberikan landasan filosofis, dasar rasionalitas dan motivasi pemidanaan; (3) mengetahui tujuan akhir dari penggunaan hukum pidana, dan (4) ditaatinya norma pidana. $^{5}$

Demikian pula ketentuan sanksi pidana penjara yang diancamkan dalam KUHP maupun di luar KUHP dibandingkan dengan jenis pidana pokok lainnya, karena pidana penjara merupakan satu-satunya pidana pokok yang ada dalam KUHP yang memungkinkan diadakannya pembinaan secara terencana dan terarah terhadap terpidana, sedangkan jenis pidana pokok lainnya tidak memungkinkan adanya pembinaan dengan terhadap terpidana. ${ }^{6}$

Sistem pemidanaan di Indonesia mencakup beberapa teori pemidanaan. Sistem ini bertujuan untuk perlindungan masyarakat untuk mencapai kesejahteraan. Sistem pemidanaan itu antara lain :

a. Teori absolut atau teori pembalasan. Teori ini memberikan statement bahwa pidana mempunyai fungsi untuk menghilangkan kejahatan pidana tersebut.

b. Teori relatif atau teori tujuan. Menurut teori ini penjatuhan pidana itu terpidana harus dibina sehingga setelah selesai menjalani pidananya, ia akan menjadi orang yang lebih baik dari sebelum menjalani pidana.

c. Teori gabungan.Teori ini muncul sebagai reaksi dari teori sebelumnya yang kurang dapat memuaskan menjawab mengenai tujuan dari pemidanaan. Teori gabungan ini berusaha memadukan konsep-konsep yang dianut oleh teori absolut dan teori relatif tujuan pemidanaan yaitu disamping penjatuhan pidana itu harus membuat jera, juga harus memberikan perlindungan sertapendidikan terhadap masyarakatdan terpidana. ${ }^{7}$ Sementara itu terjadi transformasi konseptual dalam sistem pidana dan pemidanaan yang terjadi dunia pada umumnya dari konsepsi retribusi ke arah konsepsi reformasi

\footnotetext{
${ }^{4}$ Banakar dan Travers(eds.), 2005, Theory and Method in Socio-Legal Research.(Oxford/Portland Oregon: Hart Publishing, hlm5.

${ }^{5}$ Nafi Mubarok, Op.Cit , hlm. 296

${ }^{6}$ Dede Kania, Pidana Penjara Dalam Pembaharuan Hukum Pidana Indonesia, Yustisia,Vol. 3 No.2, 2014,hlm.20

${ }^{7}$ Ruslan Saleh, 1983, Stelsel Pidana Indonesia, Aksara Baru, Jakarta, hlm. 26.
} 
ikut mendorong munculnya semangat untuk mencari alternatif pidana yang lebih manusiawi. ${ }^{8}$

Menurut Aji Haqqi, tujuan dari sistem pemidanaan adalah sebagai berikut:

1. Menghukum mereka yang bersalah atas kejahatannya, sehingga bisa menjadi kaffa'rah (pemurnian) dan reformasi mereka.

2. Bertindak sebagai pencegah bagi masyarakat untuk melakukan kejahatan.

3. Menjadi sarana retribusi bagi mereka yang menjadi korban kejahatan ${ }^{9}$

Menurut Herbert L. Packer, ada dua pandangan konseptual yang mempunyai implikasi moral yang berbeda satu sama lain, yaitu pandangan retributif dan pandangan utilitarian. Pandangan retributif mengandaikan pemidanaan sebagai ganjaran negatif terhadap perilaku menyimpang warga masyarakat sehingga pemidanaan hanya sebagai pembalasan terhadap kesalahan yang dilakukan atas dasar tanggung jawab moral masing-masing. Pandangan utilitarian melihat dari segi manfaat di mana yang ingin dihasilkan dengan pemidanaan. Di satu pihak pemidanaan untuk memperbaiki sikap perilaku dan di pihak lain dimaksudkan untuk mencegah orang lain dari kemungkinan melakukan perbuatan serupa. ${ }^{10}$

Seiring dengan perkembangan paradigm tujuan pemidanaan, maka kebijakan penanggulangan kejahatan dapat dilakukan melalui dua pendekatan, yaitu pendekatan penal (penerapan hukum pidana) dan pendekatan non penal ( pendekatan di luar hukum pidana). Integrasi dua pendekatan ini diisyaratkan dalam diusulkan dalam United Nations Congress on the Prevention of Crime and the Treatment of Offenders. ${ }^{11}$

Terjadinya pergeseran falsafah pemidanaan di atas secara simultan untuk mencari alternatif pidana perampasan kemerdekaan juga bertolak dari kenyataan, bahwa biaya yang harus dikeluarkan untuk membiayai pelaksanaan pidana perampasan kemerdekaan sangat besar. Besarnya biaya tersebut antara lain biaya hidup narapidana seperti makan, pakaian dan sebagainya yang dari waktu kewaktu menunjukkan angka yang lebih besar. Pertimbangan ekonomis di atas semakin mengedepan dan menjadi dilema oleh karena adanya berbagai kritikan terhadap berbagai upaya yang dilakukan untuk memperbaiki kehidupan narapidana, di Lembaga Pemasyarakatan, misalnya, seringkali dipahami secara tidak adil. Sering terlontar pendapat yang menyatakan dengan memberikan fasilitas di Lembaga Pemasyarakatan artinya sama dengan membantu para penjahat, sementara orang-orang di luar lembaga pemasyarakatan. ${ }^{12}$

Sementara itu berkaitan dengan pemidanaan, syariat Islam lebih memfokuskan tujuan pemidanaan pada kemaslahatan, dimana semua pemidanaan yang menghasilkan kemaslahatan individu dan memelihara kemaslahatan masyarakat adalah pemidanaan yang harus disyariatkan. Karena itu tidak boleh membatasi dengan hanya menerapkan pemidanaan tertentu tanpa pemidanaan yang lainnya.

\footnotetext{
${ }^{8}$ Taufan Purwadiyanto,2015, Analisis Pidana Kerja Sosial Dalam Hukum Positif Di Indonesia, Lex Administratum, Vol. III/No. 8/Okt/ober, hlm.158

${ }_{9}^{9}$ Abdurrahman Raden Aji Haqqi, Criminal Punishment And Pursuit Justice In Islamic Law, Al-Qānūn, Vol. 18, No. 2, 2015, hlm.313

${ }^{10}$ Marcus Priyo Gunarto, Sikap Memidana yan Berorientasi pada Tujuan Pemidanaan, Mimbar Hukum, Vol-21, No.1, February, 2009, hlm.100- 101

${ }^{11}$ Beby Suryani, Pendekatan Integral Penal Policy Dan Non Penal Policy Dalam Penanggulangan Kejahatan Anak, Doktrina: Journal of Law, Volume 1 No. (2) 2018,,hlm.71.

${ }^{12}$ Taufan Purwadiyanto, 2015,Analisis Pidana Kerja Sosial Dalam Hukum Positif Di Indonesia, Lex Administratum, Vol. III/No. 8,hlm.159
} 
Proses pemidanaan bertujuan untuk mendidik si pelaku tindak pidana bukan berarti bentuk balas dendam atas dirinya, melainkan sebagai perbaikan dirinya. Semua pemidanaan dengan berbagai bentuknya, adalah pendidikan, perbaikan, dan pencegahan yang saling berbeda sesuai dengan perbedaan tindak pidana. Pemidanaan disyariatkan sebagai kasih sayang (rahmat) dan kebaikan dari Allah terhadap hambaNya. ${ }^{13}$

Pemidanaan dalam istilah Bahasa Arab sering disebut 'uqubah, yaitu bentuk balasan bagi seseorang atas perbuatannya yang melanggar ketentuan syara' yang ditetapkan oleh Allah dan RasulNya untuk kemaslahatan manusia. ${ }^{14}$ Tujuan dari adanya pemidanaan dalam syari'at Islam merupakan realisasi dari tujuan Hukum Islam itu sendiri, yakni sebagai pembalasan atas perbuatan jahat, pencegahan secara umum dan pencegahan secara khusus serta perlindungan terhadap hak-hak si korban.

Terdapat dua aspek dasar rumusan pemidanaan dalam Hukum Pidana Islam tersebut, yaitu:

1. Aspek Ganti Rugi/Balasan (Retribution). Fungsi retributif suatu pemidanaan merupakan subjek yang paling banyak diperbincangkan oleh para ahli Hukum Pidana Islam, disamping fungsi penjeraannya. Halini tampaknya dipengaruhioleh keberadaan ayat-ayat Al-Qur'an itu sendiri yang banyak membahas tentang aspek retribusi ini. Misalnya, ayat-ayat A1-Qur'an berikut ini :

"Sesungguhnya pembalasan terhadap orang-orang yang memerangi Allah dan rasulNya dan membuat kerusakan di muka bumi, hanyalah mereka dibunuh atau disalib, atau dipotong tangan dan kaki mereka dengan bertimbal balik, atau dibuang dari negeri (tempat kediamannya). yang demikian itu (sebagai) suatu penghinaan untuk mereka didunia, dan di akhirat mereka beroleh siksaan yang besar."

Ayat Al-Qur'an di atas banyak menyebut tentang tujuan suatu pemidanaan sebagai balasan/gantirugiatasperbuatanyangmelanggarhukumtertentu. Selanjutnyamenarik untuk diperhatikan, bahwa bahasa Arab untuk kata "balasan", yaitu jaza', dalam A1Qur'an digunakan untuk kedua arti; pemidanaan (punishment) dan pahala (reward). Dengan demikian, kedua arti kata ini secara filosofis sama-sama digunakan untuk tujuan yang tidak berbeda, yaitu pemberian balasan atas amal perbuatan yang baik atau ganti rugi atas pelanggaran hukum yang telah dilakukan oleh seseorang.

Dalam hal "retribusi" sebagai alasan hukum (legal reasoning) dibalik pemidanaan, terdapat dua hal yang secara inheren menjadi unsur yang harus ada di dalamnya yakni (a) kekerasan suatu pemidanaan, dan (b) keharusan pemidanaan itu diberikan kepada pelakuperbuatankriminal.Biladibandingkandenganbentukpemidanaandalamsistem hukum pidana lain, maka bentuk pemidanaan yang dituntunkan dalam Hukum Pidana Islam ini dipandang sebagai suatu bentuk pemidanaan yang paling keras. ${ }^{15}$

2. Aspek Penjeraan (Deterrence) Pemidanaan Penjeraan menjadi alasan hukum(legal reasoning) dijatuhkannya suatu pemidanaan. Tujuannya yang pokok adalah mencegahterulangnyatindak pidana tersebut di kemudian hari. Berbeda dengan retribusi yang lebih cenderung melihat ke belakang dari titik waktu tindak pidana tersebut, maka penjeraan ini proyeksinya adalah

\footnotetext{
${ }^{13}$ Ibnu Taimiyah, al Ikhtibarat al Ilmiyah, dalam Ahmad Syafiq, Rekonstruksi Pemidanaan Dalam Hukum Pidana Islam (Perspektif Filsafat Hukum), Jurnal Pembaharuan Hukum, Vol. I No. 2 Mei - Agustus, 2014, hlm. 179-180

${ }^{14}$ A. Rahman Ritonga, dkk. 1997,, Ensiklopedi Hukum Islam, Jakarta: Ichtiar Baru Van Hoeve, ,, hlm. 1871

${ }^{15}$ Ahmad Syafiq, Rekonstruksi Pemidanaan Dalam Hukum Pidana Islam (Perspektif Filsafat Hukum), Jurnal Pembaharuan Hukum, Volume I No. 2 Mei - Agustus, 2014, hlm 185
} 
ke depan, yaitu kepentingan adanya suatu tindakan pencegahan agar pelanggaran itu tidak terjadi lagi.

\section{Permasalahan Overcrowding Penjara Di Indonesia}

Sistem perdilan pidana yang masih cenderung memenjarakan setiap bentuk tindakan pidana berdampak terhadap tingginya kriminalitas yang berakhir pada proses hukum dengan penjara sebagai tempat akhir dari sanksi hokum. Secara otomatik akan berdampak pula terhadap Overcrowding penghuni penjara di Indonesia. Tentunya permasalahan overcrowding menjadi problem tersendiri yang mengundang potensi konflik internal maupun eksternal di lingkungan lembaga pemasyarakatan maupun masyarakat secara umum.

Permasalahan (statement of the problem) dari kondisi overcrowding penghuni penjara, beresiko terhadap ketidakberhasilan konsep dan tujuan pemasyarakatan, karena konsekwensi logisnya dengan kondisi overcrowding mengakibatkan situasi krisis akibat kepadatan penghuni lapas kelebihan penghuni. Kelebihan penghuni yang dimaksud di sini adalah situasi di mana ada kelebihan kapasitas di lapas/rutan dimana jumlah narapidana lebih banyak ketimbang fasilitas, jumlah ruang, saranan prasarana yang tersedia.

Kondisi overcrowding dapat dilihat dari kepandatan penghuni lapas, dengan menganalisis pertumbuhan narapidana dibanding dengan kafasitas, dimana total tahanan dan narapidana sebanyak 262,971 dengan kapasitas 126,994 sehingga persentase Over kafasitas mencapai $107 \%$, sementara jumlah lapas dan rutan di Indonesia berjumlah 522 dengan kapasitas 126,994 orang, sedangkan isi lapas dan rutan saat ini berjumlah 262,925 orang.sebagaimanabagan berikut ini :

\begin{tabular}{lcccccc}
\multicolumn{1}{c}{ Uraian } & $\mathbf{2 0 1 4}$ & $\mathbf{2 0 1 5}$ & $\mathbf{2 0 1 6}$ & $\mathbf{2 0 1 7}$ & $\mathbf{2 0 1 8}$ & $\mathbf{2 0 1 9}$ \\
Penghuni & 159,964 & 173,572 & 204,549 & 232,080 & 256277 & 262,925 \\
\hline Kapasitas & 113,028 & 117,128 & 118,952 & 124,010 & 126,253 & 126,994 \\
\hline Tahanan & 52,636 & 56,474 & 65,545 & 70,679 & 72,997 & 69,247 \\
\hline Napi & 107,325 & 117,098 & 139,004 & 161,401 & 183,280 & 193,678 \\
\hline
\end{tabular}

Bagan Pertumuhan narapidana dan kapasitas

Sumber dari smslap.ditjenpas.go.id 20/06/2019Direktorat Jenderal Pemasyarakatan

Data penghuni lapas sebagaimana tersebut, berkonsekwensi terhadap pelayanan bagi narapidana di lingkungan lapas/rutan terutama dalam hal pengadaan bahan makanan yang dibiayai oleh APBN, dan diperkirakan pada tahun 2019 anggaran bahan makanan mencapai Rp. 1.792.071.850.000. ${ }^{16}$

Berdasarkan data tersebut negara harus menganggarkan dana hanya untuk kebutuhan makan narapidana yang bersifat konsumtif, begitu tinggi. Pengelolaan dana tersebut tentunya jauh dari standar gizi bagi warga binaan di suatu lembaga pemasyarakatan dan jika dana tersebut dialihkan untuk dana yang lain seperti halnya membuka lapanagan kerja yang produktif bagi sebanyak-banyaknya penduduk Indonesia tentu akan lebih memberi manfaat dan mengurangi kriminalitas.

${ }^{16}$ Data Statistik Pemasyarakatan , 2019, Jakarta.Direktorat Jenderal Pemasyarakatan..

44 Jurnal IUS Kajian Hukum dan Keadilan 
Sistem peradilan pidana yang masih cenderung memberikan sanksi berupa pemidanaan kurungan di lembaga pemasyarakat harus mulai memperhatikan dampak dari sanksi tersebut yang ternyata cukup efektif meningkatkan suplay penghuni lembaga pemasyarakatan yang terdiri dari narapidana dan tahanan, karena problemnya di Indonesia lembaga pemasyarakat merupakan tempat terakhir bagi setiap orang yang melakukan tindakan dan berkonflik dengan hukum.

Sampai sekarang sistem peradilan pidana belum memberikan celah bagi sanksi hukum yang sifatnya non penal berupa ganti rugi pada jenis-jenis tindakan pidana misalkan saja terhadap sanksi yang ancaman hukumannya kurang dari 5 tahun, dengan memberikan sanksi ganti rugi tersebut diharapkan menjadi solusi yang tepat untuk menanggulangi suplay penghuni lembaga pemasyarakatan. Disisi lain ganti berupa berupa uang, akan menjadi aset negara yang akan diperuntukan bagi biaya operasional kebutuhan penghuni lemabaga pemasyarakatan.

\section{Sanksi Diyat (Ganti Rugi ) dalam hukum Pidana Islam}

Fungsi dan peranan hukum dalam sebuah negara antara lain untuk (1) menciptakan keadilan yang merata bagi seluruh rakyat, (2) menjaga ketertiban dan kedamaian serta ketenangan di tenah anggota masyarakat (3) mencegah main hakim sendiri dari anggota masyarakat, (4) melindungi atau mengayomi masyarakat baik terhadap harta bendanya, jiwanya maupun kehormatannya, (5) mendorong lahirnya kesadaran untuk melaksanakan hak dan kewajiban hak dan kewajiban secara berimbang, (6) menjadikan hukum sebagai alat rekayasa sosial mewujudkan stabilitas masyarakat. ${ }^{17}$

Dewasa ini fenomena di beberapa Negara dalam hal pidana penjara mulai ditinggalkan dan sebagai gantinya dikenalkan pidana kerja sosial, pidana pengawasan, dan pidana denda. Demikian pula orientasi pembaharuan hukum pidana Indonesia haruslah memperhatikan hukum adat dan hukum Islam sebagai living law. Karena kedua sistem hukum living law Indonesia ini mengandung prinsip keadilan restoratif yang sangat tinggi dan telah teruji dalam menanggulangi kejahatan di masyarakat. ${ }^{18}$

Adanya ganti rugi (diat) dalam kajian hukum pidana Islam, pada hakikatnya merupakan perwujudan dari konsep keadilan restoratif (restorative justice) dapat diartikan sebagai sebuah metode untuk merespon tindak pidana dengan melibatkan pihak-pihak yang bertikai dalam rangka memperbaiki kerusakan yang ditimbulkan oleh tindak pidana tersebut. Hal ini dilakukan dengan dialog dan negosiasi antara kedua belah pihak. ${ }^{19}$

Tujuan restorasi ini lebih berorientasi kepada korban (victim oriented). Tujuan ini lebih untuk mengembalikan suasana seperti semula, merekonsiliasi korban (individu atau masyarakat) dan pelaku tindak pidana, dan mendorong pelaku untuk memikul tanggung jawab sebagai sebuah langkah memperbaiki kesalahan yang disebabkan oleh tindak kejahatannya. ${ }^{20}$

Perubahan paradigma menghukum dengan pidana penjara atau kurungan merupakan implementasi dari kebijakan penal kepada kebijakan non penal sebagai bentuk

\footnotetext{
${ }^{17}$ Nomensen Sinamo, 2010, Hukum Administrasi Negara.Jala Permata aksara. Jakarta, 2010, hlm.1

${ }_{18}$ Dwidja Priyatno, dalam Dede Kania, Pidana Penjara Dalam Pembaharuan Hukum Pidana Indonesia, Yustisia, Vol. 3 No.2, 2014, hlm.19-20

${ }^{19}$ Ocktoberrinsyah,Tujuan Pemidanaan dalam Islam dalam Kathleen Daly, "Restorative Justice in Diverse and Unequal Societies”, dalam Law in Context: A Socio-legal Journal, Vol. 17, No. 1, 2000, hlm. 167-168.

20 Ocktoberrinsyah,2000, Tujuan Pemidanaan dalam Islam Position Paper Advokasi RUU KUHP Seri 3 danZainal Abidin, 2000”Pemidanaan, Pidana, dan Tindakan dalam Rancangan KUHP”, tanpa keterangan, hlm. 33
} 
konkritisasi restorative justice.Sehingga hukuman pidada penjara/ kurungan yang menjadi alasan permasalahan utama overcrowding penjara dapat diminimalisir dengan bentuk sanksi hukuman berupa ganti rugi (diat) sebagai alternatif hukuman dari tindak pidana.

Hukum Pidana Islam memberikan konsep pelaksanaan sanksi pidana dengan melaksanakan diyat (ganti rugi) terutama terhadap jenis kejahatan berupa pembunuhan dalam katagori semi sengaja. Diyat secara terminology adalah harta yang wajib karena suatu kejahatan terhadap jiwa atau sesuatu yang dihukumi sama seperti jiwa ${ }^{21}$ Sayid sabiq berpendapat sebagai berikut : "Diyat adalah sejumlah harta yang dibebankan kepada pelaku, karena terjadinya tindak pidana (pembunuhan atau penganiayaan) dan diberikan kepada korban atau walinya. ${ }^{22}$

Sebagai suatu alternatif sanksi pidana dari hukum pidana Islam, ganti rugi (diyat) merupakan sanksi yang dikatagorikan sebagai pendekatan non penal dimana sanksi tersebut dibebankan kepada pelaku atas suatu tindakan yang melanggar hukum, dari konsep ganti rugi (diyat) memberikan manfaat tersendiri dalam mengurangi suplay tahanan dan narapidana yang akan menjadi warga binaan lembaga pemasyarakatan, melalui sanksi hukum yang ditetapkan oleh hakim atas suatu pelanggaran tertentu.

Pelaksanaan diyat (ganti rugi) merupakan bagian dari beberapa alasan terhadap penerapan hukum pidana Islam, Pertama, teori-teori pembaruan dalam hukum pidana Islam yang diusung para teoritisi Islam membuktikan bahwa hukum Islam mempunyai daya murunah (dinamis) dalam merespons dinamika perubahan hukum yang begitu cepat. Kedua, pembaruan teori-teori pemidanaan dalam hukum Islam merupakan jalan yang ideal dalam menemukan "titik temu" antara pemidanaan Islam dengan teori pemidanaan kontemporer. Dengan demikian pada gilirannya, hukum pidana Islam dapat dikembangkan dalam konteks pembangunan hukum nasional; Ketiga, Pembangunan hukum Pidana Islam paling ideal dilakukan dengan pendekatan maqashidy istishlahy. Artinya, untuk menyatukan figh jinayah dengan hukum pidana nasional. ${ }^{23}$

Fungsi hukum pidana menurut fikih jinayah, yaitu memiliki fungsi strategis, berupa menjamin terwujudnya kemaslahatan manusia secara utuh. Apabila hukum pidana tidak berfungsi secara maksimal, maka kehidupan manusia akan rusak dengan cepat atau secara perlahan. ${ }^{24}$ Pertanggungjawaban pidana dalam syari'at Islam adalah pembebanan seseorang dengan akibat perbuatan atau tidak adanya perbuatan yang dikerjakannya dengan kemauan sendiri, dimana orang tersebut mengetahui maksud dan akibat dari perbuatannya itu. ${ }^{25}$ Dalam syari'at Islam pertanggungjawaban itu didasarkan atas tiga hal yakni :

a. Adanya perbuatan yang dilarang,

b. Perbuatan itu dikerjakan dengan kemauan sendiri

c. Pelaku mengetahui akibat perbuatannya itu.

Terdapat empat tingkat pertanggungjawaban sesuai dengan tingkatan perbuatan melawan hukum, yaitu sengaja, semi sengaja, keliru dan yang disamakan dengan keliru. Lebih lanjut Surat al-Baqarah ayat 178 menerangkan bahwa jika dimaafkan oleh

\footnotetext{
${ }^{21}$ Paisol Burlian, 2015, Implementasi Konsep Hukuman Qishas di Indonesia, Jakarta: Sinar Grafika, hlm. 55

${ }^{22}$ Sayid sabiq, 1989, Figh As-Sunnah, Juz II, Cet. II, Beirut, hlm. 429.

${ }^{23}$ Junaidi Abdillah, 2017, Gagasan Reaktualisasi Teori Pidana Islam Dan Relevansinya Bagi Pembangunan Hukum Di Indonesia,Ijtimaiyya: Jurnal Pengembangan Masyarakat Islam, , Vol. 10 No. 1, hlm.91-92

${ }^{24}$ Muh. Tahmid Nur, 2013, Maslahat dalam Hukum Pidana Islam,Jurnal Diskursus Islam,, Vol. 1 No. 2,hlm.

${ }^{25}$ Ahmad Wardi Muslih, 2005, Hukum Pidana Islam, Jakarta: Sinar Grafika, hlm.74.
} 292. 
keluarga korban, pelaku jinayat diperintahkan untuk membayar diyat sebagai bentuk permohonan maaf kepada keluarga korban dengan cara yang baik sebagaimana telah dimaafkan dengan baik oleh keluarga korban, juga firman Al-lah An-nisa $\square$ ayat 92 ayat ini memerintahkan pembayaran diyat, kecuali jika keluarga korban berbuat baik dengan bersedekah atau merelakan tidak menerima diyat.

Berikut ayat-ayat yang dimaksud :

"Hai orang-orang yang beriman, diwajibkan atas kamu qishaash berkenaan dengan orang-orang yang dibunuh; orang merdeka dengan orang merdeka, hamba dengan hamba, dan wanita dengan wanita. Maka barangsiapa yang mendapat suatu pema'afan dari saudaranya, hendaklah (yang mema'afkan) mengikuti dengan cara yang baik, dan hendaklah (yang diberi ma'af) membayar (diat) kepada yang memberi ma'af dengan cara yang baik (pula). yang demikian itu adalah suatu keringanan dari Tuhan kamu dan suatu rahmat. barangsiapa yang melampaui batas sesudah itu, Maka baginya siksa yang sangat pedih".

Ketentuan pertanggungjawaban terhadap pembunuhan karena kekeliruan yang secara tegas disebutkan dalam surat An-Nisa $\square$ ayat 92

"Dan tidak layak bagi seorang mukmin membunuh seorang mukmin (yang lain), kecuali karena tersalah (tidak sengaja) dan Barangsiapa membunuh seorang mukmin karena tersalah (hendaklah) ia memerdekakan seorang hamba sahaya yang beriman serta membayar diat yang diserahkan kepada keluarganya (si terbunuh itu), kecuali jika mereka (keluarga terbunuh) bersedekah. jika ia (si terbunuh) dari kaum (kafir) yang ada Perjanjian (damai) antara mereka dengan kamu, Maka (hendaklah si pembunuh) membayar diat yang diserahkan kepada keluarganya (si terbunuh) serta memerdekakan hamba sahaya yang beriman. Barangsiapa yang tidak memperolehnya, Maka hendaklah ia (si pembunuh) berpuasa dua bulan berturut-turut untuk penerimaan taubat dari pada Allah. dan adalah Allah Maha mengetahui lagi Maha Bijaksana."

\section{SIMPULAN}

Berdasarkan kajian tersebut di atas, maka latar belakang permasalahan overcrowding penjara di Indonesia disebabkan karena tingginya suplai penghuni lapas/ lembaga pemasyarakatan, baik sebagai tahanan maupun narapidana. Kondisi overcrowding mempengaruhi sub sistem yang lainnya selain dari tidak terpenuhinya hak-hak dasar para wargabinaan juga berdampak pada keberhasilan tujuan pemidanaan.

Implementasi sanksi pidana diyat (ganti rugi) sebagai alternatif permasalahan overcrowding penjara di Indonesia dapat dikaji dari perspektif pemberian sanksi pidana dari pendekatan kebijakan penal yang cenderung senantiasa memenjarakan setiap bentuk kejahatan dengan penjara tanpa mempertimbangkan jenis kejahatannya, diharapkan dengan alternatif pemberian ganti rugi terutama terhadap kejahatan dalam katagori pidana umum yang ancaman pidananya tidak lebih dari 5 tahun, sehingga diharapkan akan menekan suplay penghuni lapas dan permasalahan overcrowding penjara di Indonesia akan teratasi dan tujuan pemidanaan akan sesuai dengan harapan.

\section{DAFTAR PUSTAKA}

\section{Buku}

Ahmad Wardi Muslih, (2005), Hukum Pidana Islam, Sinar Grafika, Jakarta. 
A. Rahman Ritonga, dkk. (1997), Ensiklopedi Hukum Islam, Ichtiar Baru Van Hoeve. Jakarta.

Banakar dan Travers(eds.), (2005), Theory and Method in Socio-Legal Research.(Oxford/ Portland Oregon: Hart Publishing.

Data Statistik Pemasyarakatan ,.Direktorat Jenderal Pemasyarakatan, (2019),Jakarta.

Nomensen Sinamo, (2010), Hukum Administrasi Negara.Jala Permata aksara. Jakarta.

Ruslan Saleh, (1983), Stelsel Pidana Indonesia, Aksara Baru, Jakarta.

Sayid sabiq, (1989), Figh As-Sunnah, Juz II, cet.II, Beirut.

Paisol Burlian, (2015), Implementasi Konsep Hukuman Qishas di Indonesia, Sinar Grafika, Jakarta.

Zainal Abidin, (2000) "Pemidanaan, Pidana, dan Tindakan dalam Rancangan KUHP".

\section{Jurnal}

Abdurrahman Raden Aji Haqqi, Criminal Punishment And Pursuit Justice In Islamic Law, Al-Qānūn, 2015, Vol. 18, No. 2.

Ahmad Syafiq, Rekonstruksi Pemidanaan Dalam Hukum Pidana Islam (PerspektifFilsafat Hukum), Jurnal Pembaharuan Hukum,2014, Volume I No. 2 Mei - Agustus.

Beby Suryani, Pendekatan Integral Penal Policy Dan Non Penal Policy Dalam Penanggulangan Kejahatan Anak, Doktrina: Journal of Law, 2018, Volume 1 No. 2.

Dede Kania, Pidana Penjara Dalam Pembaharuan Hukum Pidana Indonesia, Yustisia, 2014, Vol. 3 No.2.

Donny Michael, Penerapan Hak-Hak Narapidana Di Lembaga Pemasyarakatan Klas Ia Tanjung Gusta, Sumatera Utara Ditinjau Dari Perspektif Hak Asasi Manusia, 2015, Jurnal Hak Asasi Manusia, Volume 6 No. 2.

Junaidi Abdillah,Gagasan Reaktualisasi Teori Pidana Islam Dan Relevansinya Bagi Pembangunan Hukum Di Indonesia,Ijtimaiyya: Jurnal Pengembangan Masyarakat Islam, 2017, Vol. 10 No. 1.

Marcus Priyo Gunarto, Sikap Memidana yan Berorientasi pada Tujuan Pemidanaan, Mimbar Hukum 2009, Vol-21, No.1, February.

Muh. Tahmid Nur, "Maslahat dalam Hukum Pidana Islam",Jurnal Diskursus Islam,2013, Vol. 1 No. 2.

Nafi' Mubarok, Tujuan Pemidanaan dalam Hukum Pidana Nasional dan Fiqh Jinayah, Al-Qānūn, 2015,Vol. 18, No. 2, Desember.

Taufan Purwadiyanto, Analisis Pidana Kerja Sosial Dalam Hukum Positif Di Indonesia, Lex Administratum, 2015,Vol. III/No. 8/Okt/ober.

Kathleen Daly, "Restorative Justice in Diverse and Unequal Societies", dalam Law in Context: A Socio-legal Journal,2000, Vol. 17, No. 1. 